\title{
Preventing the Atrophy of the Deliberative Stance: Considering Non-Decisional Participation as a Prerequisite to Political Freedom
}

\author{
Michal Zabdyr-Jamróz \\ Jagiellonian University Medical College, Cracow, Poland \\ michal.zabdyr-jamroz@uj.edu.pl
}

Received 31 August 2018; accepted 20 January 2019; published 30 June 2019.

\begin{abstract}
In order to be exercised meaningfully, political freedom requires the capacity to actually identify available policy options. To ensure this, society ought to engage in deliberation as a discussion oriented towards mutual learning. In order to highlight this issue, I define deliberation in terms of the participants' openness to preference change, i.e. the deliberative stance. In the context of the systemic approach to deliberative theory, I find several factors causing the atrophy of such a deliberative stance. I note that this state can occur not only when debaters are representatives or are in the presence of an audience, but also when they face the prospect of a binding decision. It is the latter effect that is a serious challenge to the micro-deliberative strategy, one that strives towards decisional powers being granted to deliberative minipublics. Presenting my findings, I propose - as an alternative to the power-oriented 'ladder of participation' - a distinction between traditional co-decision and deliberative consultation, the latter one being (in certain systemic contexts) an environment that is more conducive to deliberative stance. This new typology highlights factors that lead to preference petrification and allows for the appreciation of the non-decisional character of micro-deliberation. All of it leads to the conclusion that, in order to preserve their deliberative character in the systemic context, deliberative minipublics should not always be required to have decision-making powers.
\end{abstract}

Keywords: deliberative democracy; deliberative stance; preference change; deliberative systems. 
I don't attach much importance to victory.

Nothing is so stupid as to conquer; true glory lies in convincing.

(Victor Hugo, Les Miserables)

\section{Introduction}

One of the most relevant definitions of political freedom states that it, "generally speaking, means the right 'to be a participator in government', or it means nothing" (Arendt, 1990, p. 218). Unfortunately - in the age of mediatization (Hajer, 2009), affective polarization (Druckman, Peterson, \& Slothuus, 2013) and post-truth (Keyes, 2004)-mere participation can be channeled into manipulative cooptation by a dishonest actor. It can be instrumentalized either to reinforce the dysfunctional status quo, or to support devastating, exploitative, and tyrannical changes. I would like to take advantage of this opportunity connected with the theme of this journal's issue to expand considerations on political freedom onto its background. I wish to explore its preconditions and issues that are way too often ignored or taken for granted. That is why I seemingly abandon the notion of political freedom. I am, however, keeping it in sight in order to bring it back in the end, when the proper foundations are set.

Thus, in this paper, I focus on prerequisites of the meaningful practicing of political freedom as the capacity of an individual or a group to formulate and comprehend a substantial spectrum of policy options to choose from. I will focus not merely on the objective possibility of such options, but also on the realization of what these options really are. I argue that political freedom of a person cannot be fully realized without the person's willingness and ability to listen to others, thus expanding her or his understanding of the issue. In other words, I insist that political freedom requires and demands - at least at some point - an engagement in deliberation. I therefore emphasize the role of certain conditions of modern political discourse as structural barriers. In my view they limit our scope of public imagination, narrowing policy options to those dictated by our preexisting preferences, i.e. ideologies, emotions, and self-interests. In other words, I argue that political freedom implies a duty to listen.

Listening became a focal point of Andrew Dobson's book titled Listening for Democracy: Recognition, Representation, Reconciliation (2014). It also turns out to be a core idea within the theory of deliberative democracy that emphasizes the role of learned discussion - deliberation - as a way of shaping political will in a democracy (Dryzek, 2002, p. 32; Held, 2006, pp. 125-184). The openness to opinion change through such deliberation should be considered as the defining feature of deliberation. On that note, David Owen and Graham Smith (2015, p. 228) introduced a concept of 'deliberative stance', i.e. "a relation to others as equals engaged in the mutual exchange of reasons oriented as if to reaching a shared practical judgment". For the purposes of this paper (focusing on the "shared judgement" aspect), I define the deliberative stance as an attitude of being open 
to position change in response to arguments and reasons provided by others in a discussion (i.e. a conversation with a difference of positions). It is an inherent element of deliberative "weighing and reflecting" (Mansbridge, 2015, pp. 27-49). Participants' willingness to agree with a better argument or accept someone else's greater needs is what distinguishes deliberation from other forms of public discourse, i.e. debate and bargaining. The reality of politics, however, usually leads to those very forms. In debates (1), participants take an eristic stance, employing the Arthur Schoppenhauer's (2005) The Art of Always Being Right in order to "win the argument" (e.g. in order to convince the spectators) "without regard to truth o reason", thus being persistent and uncompromising in standing by their prior views. On the other hand, egocentric bargaining (2) occurs when participants are willing to change their position, but only under the condition of receiving something in return. Both of these non-deliberative stances, i.e. an uncompromising mindset and benefit seeking, lead to the atrophy of the deliberative stance and the atrophy of deliberation itself.

The atrophy of deliberation is the absence or decay of a deliberative stance among participants of a debate. This phenomenon — referred to as positional politics—represents a crucial flaw in many parliamentary discourses (Steenbergen, Bächtiger, Spörndli, \& Steiner, 2003). It is also one of the most challenging problems for deliberative democratic theory, especially for the 'micro-deliberative strategy' that strives for decisional powers to be granted to deliberative minipublics (Thompson, 2008), i.e. the methods of the practical implementation of deliberative ideals, such as deliberative opinion polls (Fishkin, Luskin, \& Jowell, 2000). As David Owen and Graham Smith claim, "We need to better understand the challenges of adopting and cultivating the deliberative stance within the "unruly politics of social life"" (2013, p. 229). They pose the following question: "to what extent and under what circumstances do partisanship, expertise, consumption practices and the like sustain or undermine the conditions for taking up a deliberative stance?" (Owen \& Smith, 2013, p. 229). In other words - why and how is deliberative stance undermined?

The recent systemic turn in deliberative democratic theory provides an appropriate perspective for this issue (Mansbridge et al., 2012). Rather than being oriented merely towards deliberative techniques or methods known as minipublics (a narrow deliberative approach), it introduces the concept of a deliberative system as a certain totality of deliberative and non-deliberative practices yielding 'deliberative' results. It searches for deliberative qualities not in individual debates, but in the entirety of the deliberative system (Elstub \& McLaverty, 2013). In some instances, it answers the call for an "integrative" or "ecumenical approach" by combining benefits of micro and macro deliberative theories (Hendriks, 2006; Goodin, 2008; Dryzek, 2010a). The latter one, however, is criticized for insisting on granting decision-making powers to minipublics. Such a gesture, as Cristina Lafont (2015) argues, would diminish rather than improve the democratic legitimacy of the deliberative system. By introducing the concept of the decisional atrophy of deliberative stance, I also wish to approach critically the notion of decision-making micro-deliberation. 
Firstly, I distinguish deliberation from other types of discourse, namely debate and bargaining. By linking deliberation with social learning, I find out that the most popular typology of citizen participation, namely Sherry Arnstein's (1969) ladder of participation, might require a serious revision, since it ignores the educational aspect by being entirely decision-centered. With this, I identify the phenomenon of the decisional atrophy of deliberative stance as well as I propose a distinction between co-decision and consultation, generating a typology that is alternative to the power-oriented ladder of participation. This new typology highlights factors that lead to preference petrification and allows for the appreciation of the non-decisional character of deliberative minipublics within the entirety of the deliberative system.

My proposition draws from this systemic turn in its key point, i.e. through the consideration of deliberative democratic theory as complementary rather than antagonistic to other forms of democracy (with their non-deliberative mechanisms, such as voting, strikes, protests, and even eristic debates), and the searching for ways to improve the deliberative qualities of the entire political system. However, I strive to achieve this goal by exploring a notably different path. Instead of perceiving deliberation in a systemic and expansive way, I restrict it to a single discursive event (discussion) and to a pure type of discourse, one that is distinct from bargaining and debate. I do this on an analytical level in order to study the potential place for such a deliberation in the deliberative system. Thus, I link the narrow, microdeliberative approach - focused on deliberative methods in one place at a given time, as represented by authors such as James Fishkin (2011) or Adolf Gundersen (2000) — with the systemic one (Mansbridge et al., 2012) that derives from the discursive approach (Dryzek, 2002; Habermas, 2002). This will allow me to more aptly fulfill the goals of the systemic approach, namely the identification of "(a) the occasions and sites of deliberation and (b) the discursive scaffolding that supports good deliberation” (Owen \& Smith, 2013).

\section{Deliberation: Theoretical Remarks}

I define 'deliberation' in a narrow sense, i.e. as a discussion (a structured conversation with a difference of opinions) with the prospect of preference change among its participants (unlike in a debate) that is not conditioned by benefits (unlike in bargaining); the said preference change may be the result of learning from others about their reasons, selfinterests, emotions, etc. Therefore, the defining feature is the prospect of opinion change, i.e. the openness of listeners (though this one is difficult to operationalize) rather than the actual opinion change, the latter of which might not occur due to insufficient argumentation. It is an approach that should be distinguished from a broader, i.e. discursive approach (Smith, 2013), which is a precursor to the systemic turn (Owen \& Smith, 2013). The discursive approach identifies deliberation as the entirety of public discourse as it encompasses various kinds of communicative events within the public domain, resulting in a hypothetical preference change, albeit not so much by the participants but, rather, by the audience. Although this seems fundamental in the new systemic approach, for analytical reasons I will use the aforementioned narrow definition. 
Following Simone Chamber's reservations (2012, p. 59), one has to admit that this approach stands also in stark contrast to the definition proposed by Joshua Cohen, for whom deliberation "is about weighing the reasons relevant to a decision with a view to making a decision on the basis of that weighing" (2007, p. 219). I have nonetheless selected it for two reasons. Firstly, having in mind Gundersen's (2000) notion of "dyadic deliberation", I wish to analyze deliberation as a conversation that involves at least two persons with a difference of opinions on how a given issue should be resolved, while Cohen's definition seems to include even a kind of "solitary deliberation" (Goodin, 2000). Secondly, the author concentrates on the decision-making aspect, whereas I intend to focus on the deliberative stance, i.e. an attitude of openness to opinion change that is unique to this type of discourse. In fact, I will consider the prospects of a binding decision-made unanimously or by a majority - as a factor influencing this specific attitude. Here, it is this mere openness to opinion change that defines deliberation and not its outcome, be it a consensus or even an actual change in preference distribution. Such an outcome, as Michael Fuerstein puts it, should rather be considered as an essential byproduct of deliberation, i.e. "a goal that can be intentionally achieved only as a consequence of aiming at some other objective" (2014, p. 282; Elster, 1983).

\subsection{Deliberation versus Debate and Bargaining: Deliberative Stance and Social Learning}

As Owen and Smith (2013, p. 228) put it, deliberation is not just any talk; it is "only that talk that emerges from a deliberative stance amongst participants". Therefore, I treat deliberation as a particular, pure/ideal-type of debate, similar to the "type I deliberation" introduced by André Bächtiger et al. (Bächtiger, Niemeyer, Neblo, Steenbergen, \& Steiner, 2010), which is clearly distinguished from other pure/ideal-types of debates, such as:

(1) bargaining - a discussion based on a mutual exchange of concessions, where benefit-seeking participants (oriented towards self-interest) change their mind only when gaining something in return;

(2) debate - a discussion that is based on positional politics, where participants (debaters) are oriented towards convincing audiences (non-debating spectators) rather than each other, and arguments are meant not to convince interlocutors, but to 'defeat' them.

Debates are often equated with deliberation. Here, however, I distinguish these terms to label different concepts. Claudia Landwehr and Katharina Holzinger (2010, p. 378) identify the etymological origins of the term by explaining that "the French origin, 'débattre', meaning 'to defeat, to strike down', (figuratively) points to the goal of participants in a 
debate. Groups are pre-defined, and they present rather than exchange arguments". Debaters are usually characterized by an "uncompromising mindset" (Gutmann \& Thompson, 2012, p. 65) that drives their positional politics. ${ }^{1}$

Bargaining (or hard bargaining) should be distinguished from negotiation. The latter one, according to Mark Warren and Jane Mansbridge (2013) can take a form of a "deliberative negotiation". It is a negotiation that includes self-interests, but respects the deliberative ideals of mutual respect, equality, reciprocity, mutual justification, fairness, and non-coercion. Unlike the usual bargaining that employs the strategic control of information, deliberative negotiation treats information on the actual self-interest of parties as a required input to be considered with solidarity, not as a hidden agenda to be won at someone else's expense. ${ }^{2}$

This analytical stand ${ }^{3}$ will allow me to position deliberation within a wider and long-duration systemic context, i.e. in relation not only to other areas and forms of the public discourse, but also to the dynamics of changing political processes. Here, I should also note that the atrophy of deliberative stance that I wish to investigate here is a concept wider than just positional politics (or an uncompromising mindset), because the latter one means an absolute persistence, one that is immune even to bargain. ${ }^{4}$ The atrophy of deliberative stance is persistence that is immune to reasons or arguments motivated by general interest,

\footnotetext{
${ }^{1}$ In Landwehr and Holzinger's (2010) typology, deliberation is an "essentially decision-related interaction". Deliberation, as it is understood here, corresponds more to their 'discussion'.
}

${ }^{2}$ I agree with Mansbridge et al. (2010) when they say that self-interest plays a legitimate role in public deliberation and "deliberative negotiations" should be considered beneficial in a wider, systemic context. After all, they result in preference change. However, my goal here is to treat deliberation as a certain pure type of discussion, one that is distinguished form debate and bargaining. This is because even though self-interest does not necessarily have to dominate one's motives (Mansbridge, 1990), the context and the mode in which it is employed in a debate (its institutional arrangement) determines how the preference discrepancy will be dealt with. For instance, bargaining introduces self-interest in a very different way than deliberation or deliberative negotiation does. In the latter one, needs should be honestly declared so that they can be included in the common interest. Bargaining, on the other hand, might require concealing true interest so that a strategic advantage can be gained.

\footnotetext{
${ }^{3}$ These three types of discourse can be located on the two-dimensional typology proposed by Chambers, where she juxtaposes the Socratic and democratic perspectives of reason. Deliberation refers to "robust reasoning and general appeal", where justification can be shared by general public (public Socratic reason) and motivation is the public interest (public democratic reason). Negotiation (preferably taking place behind closed doors) is a "well-reasoned debate [public Socratic reason] that takes private reason as its starting point" (private democratic reason). Debates, mainly conducted in public, fail the Socratic criterion by employing "shallow" or "plebiscitory" reasoning. It can have either a narrow or a general appeal. In the latter case, "the public nature of the debate [public democratic reason] forces speakers to make general appeals, but there is little or no critical accountability to ensure that those appeals are well reasoned [plebiscitory Socratic reason]" (Chambers, 2004, p. 398).

${ }^{4}$ Perhaps one of the finest eulogies for the deliberative stance and bargain was made by Edmund Burke in his famous Speech to the Electors of Bristol of 1780, in the fragment "on the responsibilities of a Member of Parliament". He spoke against the "coercive authority of [electors'] instructions", i.e. against "determination that precedes discussion". As he said, "Parliament is not a congress of ambassadors from different and hostile interests; which interests each must maintain, as an agent and advocate, against other agents and advocates; but parliament is a deliberative assembly of one nation, with one interest, that of the whole; where, not local purposes, not local prejudices, ought to guide, but the general good, resulting from the general reason of the whole" (Burke, 2011).
} 
but preferences here can be changed by mutual concessions of self-interests. Positional politics is persistence that is immune to all arguments and mutual concessions between private self-interests.

Openness to preference change that is also open to self-interests of others, albeit in a nonegocentric way, invokes John Dewey's idea of classroom discussion as face-to-face talk, in which participants are focused on "responding to the substance of individual utterances", and where the teacher is merely a moderator (Kosnoski, 2005). In a wider, systemic context, it modifies the role of democratic leadership, turning it into political pedagogy that seeks "a strategy for slowly but dramatically reworking social structures and collective identities" (Mariotti, 2014). It goes along Ralph Waldo Emerson's concept of liberal democracy, which allows for the continued revision and refinement of liberal political values (von Rautenfeld, 2004). In this instance, deliberation is to be considered as a unique process of political learning (or social learning), a type of process involving

[...] not the simple imposition of an abstract, preconceived standard of rationality but, rather, a commitment to politics as an open-ended and continuous learning process in which the roles of 'teacher' and 'curriculum' are raised, and where the matter of what is to be learnt has to be settled in the process of learning itself. (Held, 2006, p. 168)

\subsection{Deliberation as Consultation on the 'Ladder of Citizen Participation'}

A common element of strictly deliberative methods in recent practices, the so-called minipublics, is their evidently consultative status in relation to political power. They are designed as merely advisory bodies for those who make decisions. The results of such deliberation are not binding in terms of the final decision. According to the influential concept of $A$ Ladder of Citizen Participation by Sherry Arnstein (1969), deliberative techniques identified in such a way should be perceived as a merely symbolic form of participation, i.e. "tokenism" (see: Figure 1).

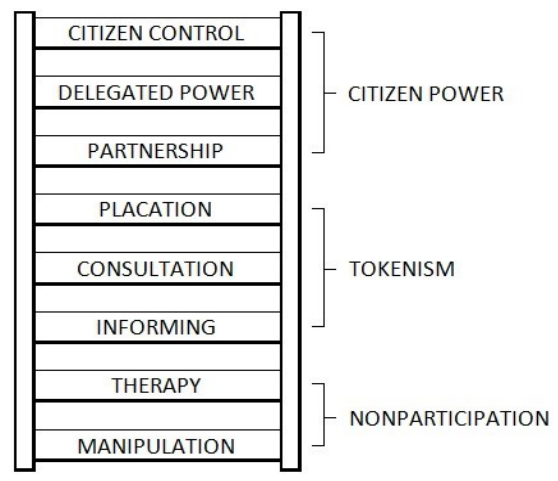

Figure 1. Eight Rungs on the Ladder of Citizen Participation. Based on A Ladder of Citizen Participation by Sherry Arnstein (1969) 
Perceiving deliberation as merely token participation is a result of a quasi-quantitative approach to the issue; the position on the ladder of participation depends on the "amount of power" that the method provides citizens with. From this perspective, the only reasonable participation method is co-decision. This, of course, was the explicit intent and a conscious theoretical choice of Arnstein (1969, p. 216) when she declared that "participation is a categorical term for power". Thus, the ladder describes only the extent of citizens' access to power over themselves in the struggle with official authorities.

In 2006, Kevin Collins and Ray Ison (2006, p. 2) pointed out that "despite the plethora of tools and methods available, [...] Arnstein's ladder of citizen engagement remains, implicitly and explicitly, at the core of many approaches to participation despite being published some 40 years ago". Conceptualized in such a way, of course, the framing stimulates citizens' empowerment. However, it also has consequences for how participation is practiced. It limits the practitioners' awareness of involvement, i.e. the expected conditions, results, and processes. Without a proper epistemological inquiry into this issue, "practitioners and researchers run the risk of using tools, practices and techniques inappropriately, with undesirable consequences for policy development and policy outcomes" (Collins \& Ison, 2006, p. 4).

There are various critiques of Arnstein's ladder (Tritter \& McCallum, 2005). In this context, Collins and Ison (2006, p. 5) conclude:

[...] we suggest that Arnstein's ladder, with its focus on power, is insufficient for making sense of participation at a conceptual or practice level. We suggest that our understandings of participation need a new footing and it is perhaps time to jump off Arnstein's ladder.

What the authors recommend is an alternative policy paradigm of social learning. Within this paradigm, participation is a necessary, but not a sufficient condition to progress towards "concerted action among multiple stakeholders" (Collins \& Ison, 2006, p. 12). From the perspective of deliberative theory, what Arnstein's 'amount of power' perspective ignores is the important advantages of consultative deliberation, i.e. a whole range of epistemic issues. It does not take into account the qualitative aspect of participation, particularly the freedom of discussion and preference change that is not bargaining-based.

\section{Factors Affecting the Atrophy of Deliberative Stance}

The atrophy of deliberative stance is a situation in which the participants in a given discussion become unwilling to change their minds regardless of provided arguments and reasons; they maintain their opinion rather than admit that the opposite one is better (positional politics), or they are willing to change their stance only if the others offer them something in return (the possibility of bargain).

The prospect of opinion change constitutes 'constructive politics', which is one of the five coding categories of the Discourse Quality Index (DQI). In 2003, when the Index was first applied to the proceedings of the House of Commons in the UK, it turned out, not surprisingly, that the parliamentary debate — in spite of its high discourse quality — failed miserably 
when it comes to constructive politics. MPs were entirely unwilling to change their minds; all of their speeches represented positional politics (Steenbergen et al., 2003). The same result was confirmed for the German Bundestag, even when the party discipline was suspended (Landwehr \& Holzinger, 2010). This problem is not new and it did not go unnoticed by Carl Schmitt (1988) in the turbulent times of the interwar period; it was a proof of the degeneration of the European parliamentary democracies.

In the case of the mentioned DQI in the UK in 2003, researchers speculated that this had been due to the competitive nature of the British political system (Steenbergen et al., 2003). I believe that the reasons for this are much more profound and universal, namely that this competitiveness is a result of certain structural arrangements. When certain procedural conditions are not met, what one observes is the atrophy of deliberative stance. This appears to be particularly problematic when the result of the deliberation is supposed to be binding for a given policy issue.

\subsection{Decisional Atrophy of Deliberative Stance}

Decisional character is the impact of a given forum on the shape of a policy discussed. It is something much stronger than the 'coordinateness', described by Landwehr and Holzinger (2010), because a discussion can be 'coordinated', i.e. being arranged to produce a collective outcome, but still can have no impact on the final political decision. The very awareness of such a decisional nature of a given discussion among its participants is a factor in changing the terms of a discussion. It generates a combination of socio-psychological phenomena within the deliberative body and outside of it. From the deliberative perspective, however, it is not certain whether this influence is strictly a positive one. Presumably, decisional character generates greater interest and participation. The awareness of the gravity of the discussion provokes more responsible participation; it encourages an increased focus and actual engagement. However, a more serious approach to the problem also entails a more rigorous appraisal of one's values or interests (irrespective of whether they are a matter of private self-interests or religious beliefs). Ian Shapiro (1999) points out that, in some cases, deliberation can only induce conflict by bringing "differences to the surface" and "widening the political divisions rather than narrowing them". This in itself can be a positive thing from the deliberative systems perspective, yet it still might not be conducive to a highquality micro-deliberation. In many cases, the mere prospect of a binding decision can provoke polarization and thus undermine the conditions for genuine deliberation. I shall call this hypothetical phenomenon the decisional atrophy of deliberative stance.

The above-mentioned hypothesis is based on the remarks from John Dryzek (2005, p. 237) on one of the key mistakes of the "discursive engagement in a semidetached public sphere". It is not only about the lack of autonomy in the public sphere, or the complete non-responsiveness of the authorities, but also about the "too tight a connection between [the] public sphere and sovereign authority”. In Dryzek's view (2002, pp. 87-107), the 
latter problem lies primarily in the systemic co-optation of public-sphere actors to the centers of power (the state). Stakeholders involved in the decision-making process are no longer willing to sincerely express their opinions in the public space. Dryzek notes that such "groups" entry into the state" (center of political power) tends to leave a "depleted civil society" behind. This is why, paradoxically, a "more democratic state" can mean a "less democratic polity" (Dryzek, 2002, p. 111). However, this is a manifestation of the phenomenon at the macro level. At the micro level-in a discussion-participation in power might also impair the deliberative stance by damaging the mechanism of selecting an opinion, i.e. of sieving those opinions that are not sufficiently substantiated. Here, I focus on the error of "making deliberation decisional" at the micro level specifically.

In my view, the primary mechanism of the decisional atrophy of deliberative stance would be as follows. When stakeholders realize that the result of deliberation can have profound consequences for their vested interests, they take action to protect these interests by means of political marketing, lobbying, etc., all of which is addressed towards actual or potential participants of such a deliberation, thus leading to preexisting opinion petrification (Kahan, Peters, Dawson, \& Slovic, 2013). When strong ideologies or ethical standpoints come into play, preferences are entrenched and the use of deliberation turns out to be counter-effective in terms of yielding preference change (Abelson et al., 2003). Such ineffectiveness of deliberation has been observed in the case of conflicts of self-interests, e.g. in health care rationing (Shapiro, 2003, pp. 36-37). In such cases, deliberative bodies turn into arenas of struggle for sovereign power. Learned discussion is replaced with a debate with voting and/or bargaining of self-interests.

On the micro level, the decisional atrophy of deliberation occurs when the mere expectation of a binding decision causes a change in the external and internal conditions of deliberation, which results in the decay of a deliberative stance among the participants of deliberation. It leads to a situation where deliberating parties are either indoctrinated, reminded, or made aware of their vested interests and ideological standpoints. It changes their role in the process and modifies the conditions for preference change, making such a change harder to acquire through argumentation. In the context of the specific nature of this role, the necessity to resolve the controversy (when opinions are rigid) leads to typical forms of decision-making, i.e. arbitrary individual decisions, voting, bargain, or expertise. The idea of a deliberative preference change through learned discussion might not be structurally compatible with such aggregative forms of civic participation (a social dialogue involving the representation of a particular interest group or a particular vision of the common good). It might be the very structure of these forms (primarily the nature of participation as representation) that provokes the petrification of opinions.

\subsection{Consultation and Co-Decision: An Alternative to the Ladder of Participation}

As a theoretical description of this issue, and in reference to Arnstein's 'ladder', I propose the following, provisional qualitative distinction between two ideal types of citizens' participation: traditional co-deciding and deliberative consultation (Zabdyr-Jamróz, 2011). 
Typically, when it comes to participatory methods other than just voting, citizens' codecision mechanisms mostly involve some kind of a corporate representation of stakeholders (parties, interest groups, selected communities, ideological positions, etc.) or, at the very least, the presence of elites with particular competence (expertise, experience, or special involvement in the issue). These participants are opinionated mostly by default, i.e. through the relation of representation. In contrast, deliberative consultation involves ordinary, lay citizens merely presenting themselves (as a 'representative sample'). They participate in a debate with their own mind and if, by any chance, they are convinced by the power of arguments, they can change their opinion, since they are not bound by a special relation to anyone.

Differences between these two models are presented more elaborately by means of the table and description below. This analytical distinction shows that there are certain structural hindrances to deliberation and that the actual roles performed in participation shape its character and the outcome. It is significant to note that the differences between codecision and consultation are not limited to formally granted competences. Some de iure 'consultative' or 'advisory' bodies can, in practice, function as co-decision bodies, especially when the participants' authority cannot be ignored by decision-makers. It is mainly the structure of a given discussion, i.e. its subject and character of participation (representation), that determine the role of participation. The following distinction does not imply that deliberative minipublics should not and cannot have decisional powers. It is merely to indicate certain factors that may lead to the atrophy of the deliberative stance.

Table 1. Traditional Co-Decision versus Deliberative Consultation

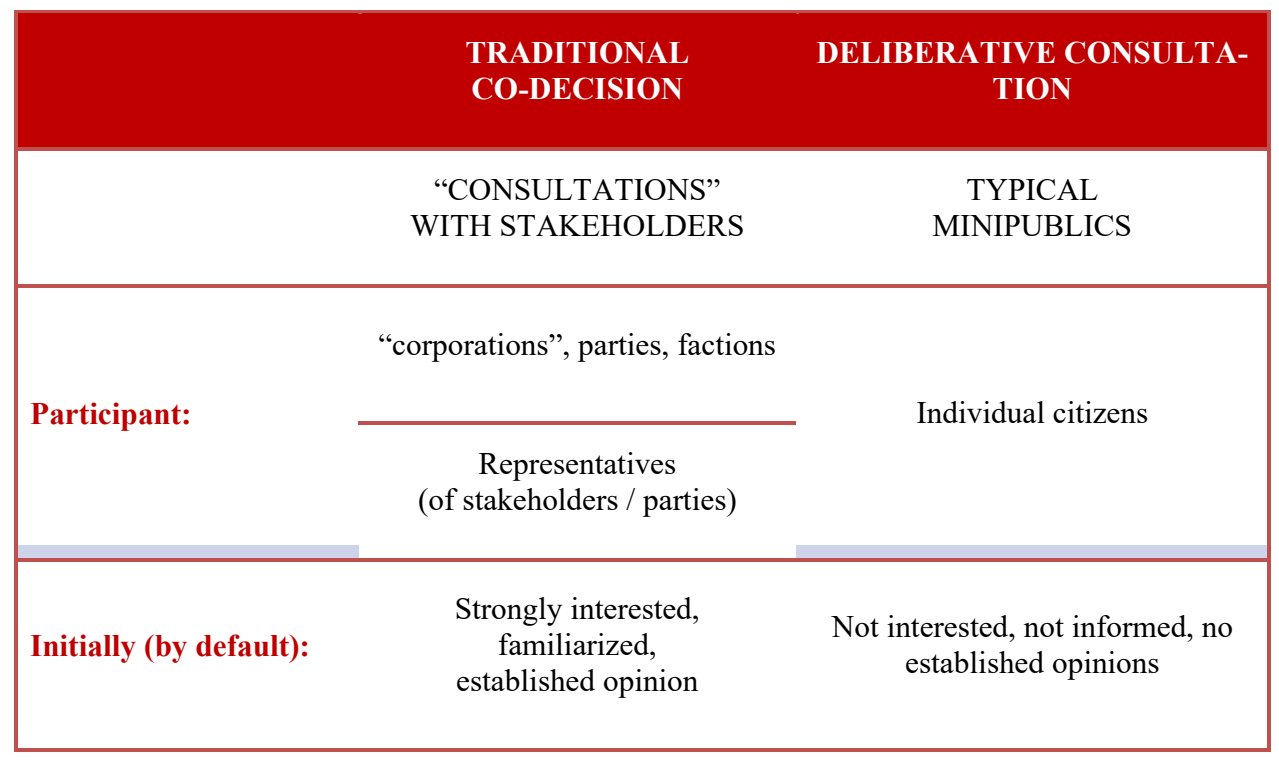




\begin{tabular}{|c|c|c|}
\hline \multirow{2}{*}{ Function: } & $\begin{array}{l}\text { Expression of developed } \\
\text { preferences }\end{array}$ & Development of preferences \\
\hline & $\begin{array}{l}\text { Aggregation of preferences } \\
\text { (ideologies, interests) } \\
\text { and/or providing expertise }\end{array}$ & Social learning \\
\hline $\begin{array}{l}\text { Participation } \\
\text { paradigm: }\end{array}$ & $\begin{array}{l}\text { REPRESENTATION } \\
\text { of particular interests } \\
\text { or particular visions of } \\
\text { the common good }\end{array}$ & $\begin{array}{c}\text { PRESENTATION } \\
\text { of citizens' judgments } \\
\text { (participants 'represent } \\
\text { themselves') }\end{array}$ \\
\hline Discourse type: & $\begin{array}{c}\text { BARGAINING } \\
\text { (reciprocal concessions) } \\
\text { or DEBATES } \\
\text { (to 'win' in the view of } \\
\text { decision-makers, voters, etc.) }\end{array}$ & $\begin{array}{c}\text { DELIBERATION } \\
\text { (discussion with prospects of } \\
\text { deliberative preference change) }\end{array}$ \\
\hline Goal: & DECISION-MAKING & LEARNED OPINION \\
\hline Result: & Decision (obligatory) & Preference change (expected) \\
\hline \multirow[b]{2}{*}{ Approach: } & Factional-collective & Holistic-individual \\
\hline & $\begin{array}{l}\text { Particular self-interests or com- } \\
\text { peting visions of } \\
\text { common interest }\end{array}$ & $\begin{array}{c}\text { Public justification, } \\
\text { common interests } \\
\text { or legitimate self-interests }\end{array}$ \\
\hline \multirow[b]{2}{*}{ Prerequisites: } & Issue networks & Demos \\
\hline & $\begin{array}{c}\text { Background institutions-per- } \\
\text { manent partners of } \\
\text { authorities }\end{array}$ & $\begin{array}{l}\text { No background- } \\
\text { random sample }\end{array}$ \\
\hline
\end{tabular}

Deliberative citizens' consultation and traditional co-decision have different subjects. Non-decisional deliberation involves more general political topics, ones that are not particularly controversial for establishing the overall principles of a given policy. Consultations are often practiced at the policy level so that the preferences of the local community in terms of the allocation of resources can be investigated. They are mostly used as a way 
to improve the responsiveness of governance. Issues that are political and highly controversial, i.e. marked by strong ideological involvement as well as those concerning particular self-interests, are not compatible with deliberation. What is crucial here is that often the subject of discussion (whether it is controversial or not) determines the actual character of the participation and the role of participants ('do I feel like a representative of a given doctrine?'), thus shaping their attitudes and behaviors.

\subsection{The Role of Participants}

What coincides with traditional co-decision is the elite status of participants and the representative character of their role. Quite often (though not always), the actual decision-making bodies are composed of experts, stakeholders' representatives (opinion leaders), and government officials. Frequently (even within 'consultations'), certain opinions (particularly those held by experts and stakeholders' representatives) become, in fact, binding because of their high authoritativeness. Due to either the expertise or the fact that the opinion is given on behalf of an important stakeholder, the decision-maker is compelled to treat such advice as binding. In effect, the merely 'advisory' body has, in fact, a decisional character.

Such a character of the role performed in the discussion is the reason why it is somewhat difficult to change the opinion of its participants. Vested interests and ideological engagement - often supported by experts' opinions — are both typical characteristics of co-deciding civil society actors, namely labor unions, lobby groups, political associations, thinktanks, etc. These participants are mostly part of the 'issue network', i.e. wide range policydevelopment partners of the government that are constantly 'on standby' (always interested in the issue, always opinionated, and ready to engage and present their case). They have certain preconceived convictions and fixed points of agenda, usually ones based on vested interests and ingrained ideologies that, by default, are difficult to change.

Interestingly, even convictions built on the basis of expert knowledge and practical experience in a given subject have a tendency to stiffen and be resistant to empirical evidence that contradicts them. As Philip E. Tetlock (2005, p. 191) concludes, "Experimental psychologists have found that many judgmental shortcomings can be traced to a deeply ingrained feature of human nature: our tendency to apply more stringent standards to evidence that challenges our prejudices than to evidence that reinforces those prejudices". In fact, as Dan Kahan's (2013) research shows, those who are more competent also tend to be more opinionated in political issues, and use their better skills to defend their convictions in spite of the challenging evidence, sometimes even obscuring the facts. This conclusion has been confirmed by Jane Suiter et al. in the context of the application of deliberative methods. As the authors state:

Those who may be of higher social standing - that is, those who are older and are more knowledgeable - tend to change their minds less than those with lower levels of knowledge or who are younger. This is particularly the case for more salient issues. (Suiter, Farrell, \& O’Malley, 2014) 
Thus, when it comes to the deliberative stance, a crucial structural divergence between deliberative consultation and traditional co-decision should be emphasized, namely that the nature of the participation determines the chance of changing opinions through discussion. In co-decision (bargaining, voting preceded by debates, or even expert-advising decision-makers), just as in typical forms of aggregative democracy, the participants of discussion are representatives of a variety of bodies (political parties/the electorate, their interest groups (stakeholders), or even their field of expertise) (Wagner, 2014). These participants are, by definition, limited to their mandate, be it explicitly or implicitly. A free mandate (one that allows for a change of opinion) involves either the free hand in establishing a political program (as the realization of the will of the electorate) or the possibility of making mutual concessions within bargaining, thus leading to a compromise. This means that a change of heart on the participants' part (due to reasonable argumentation, which is the desired effect of deliberation) would be a betrayal of their mandate. If they make some concessions, backing down from their position, it is only as a result of acquiring reciprocal benefits from the other party. Similarly, when one modifies an ideologically motivated position (within a political, religious, or ethical doctrine), at the very least they are obliged to insist upon certain fundamental assumptions. Such people are perceived, and perceive themselves, as representatives of a given system of ideas.

The participants of consultative deliberation, however, do not represent anyone or anything except for constituting a 'representative sample' of the population. They are presenting themselves, their views, and their opinions in person (Badiou, 1988, pp. 95-115). In principle, they are not bound by any constraints (e.g. instructions from a mandatary). A change of their opinions as a result of deliberation is supposed to simulate how the distribution of preferences within a population would change if the entire population were able to take part in a form of dialogic learning (Fishkin, 1991, p. 81). That is why strictly advisory deliberative methods focus on lay citizens, i.e. persons who are uninvolved and not well-versed in the issue, which comes down to those who do not have undue preconceptions. This is also why, while all citizens have interests (stakes) in public issues, these 'lay citizens' are distinguished from 'stakeholders', i.e. those who are part of the issue network (Kahane, Loptson, Herriman, \& Hardy, 2013). ${ }^{5}$

\footnotetext{
${ }^{5}$ An interesting example of the successful disarmament of the atrophy of deliberative stance in a representative body is the German Conference Committee (Vermittlungsausschuss), i.e. a forum, whose objective is to reconcile legislative conflicts between the two parliamentary houses. It is characterized by a high level of constructive politics; however, this is evidently due to certain extraordinary arrangements. Firstly, in this forum, a consensus or a compromise is required and presets the outcome of the discussion, which is a criterion of its success. This probably even distorts deliberation by enforcing a conciliatory approach or even a bargain; it makes a preference change mandatory (unlike in the true deliberative stance). Secondly, "public pressure is relatively low, since [Committee's] discussions are confidential; thus, the participants can act as trustees. Thus, although they are still representatives of their constituencies, they are more likely to change their opinion in the light of alternative arguments" (Spörndli, 2003). A similar example of the advantageous discursive conditions would be the Constitutional Convention of 1787 in Philadelphia, which deliberated in secret, unlike the French Assemblée Constituante of 1789 that was held in public (Elster, 1995, p. 251). A good deliberative quality of the former one, as
} 


\subsection{The Structure of Debate, the Role of the Audience}

Steven Skultety (2009, p. 44) argues that "the very structure of political deliberation is competitive", at least as "competition among proposals". However, the degree and quality of such a competition are variable in different types of discussion. The type of participation determines motives, incentives, and relationships between participants. Strictly deliberative forms have the so-called 'cool' structure; they are designed is such a way so that participants do not become rivals (in contrast to 'hot' decision-making bodies, where interests and ideas compete) as they strive to support a joint search for a solution to a problem (Fung, 2003). Deliberation should be governed by what has been described by Monique Deveaux (2003) as the "revisability" principle, i.e. a rule guaranteeing that if anyone changes their mind on an issue, they do not lose the respect of others. In such cases, dissent is considered a contribution to the discussion.

In this respect, an interesting dilemma occurs concerning one of the most appraised republican concepts, namely "emulation". John Adams (2011, pp. 232-233) used this term to describe a virtue derived from "the passion for distinction". As he stated:

Wherever men, women, or children are to be found, whether they be old or young, rich or poor, high or low, wise or foolish, ignorant or learned, every individual is seen to be strongly actuated by a desire to be seen, heard, talked of, approved and respected by the people about him, and within his knowledge. (Adams, 2011, pp. 232-233)

The opposite negative expression of this passion is ambition, which is a vice of tyrants, because it "aims at power as a means of distinction". It is tyrannical, because it is a desire to permanently rise above others, and it tends to destroy all political life. The virtue of emulation, on the other hand, desires to merely excel and, in fact, requires the company of one's peers ("to be seen in action"), thus fueling participation and creating demand for the public sphere. This virtue of emulation was even presented by Hannah Arendt (1990, pp. 120-121, 136, 196-202) as an essential factor for true political emancipation. However, from the deliberative point of view (bearing in mind the virtue of open-mindedness), there is a darker side to this noble desire, because it creates a fertile ground for the 'audience democracy', where discursive performance is rewarded by audience appraisal as well as by voting decisions reached after the discussion. Unfortunately, neither of these 'rewards' is deliberation-friendly. They do not reward the actual problem-solving through social learning, but merely endorse the rhetorical triumph over others, as in so-called Claro! cultures that are characterized by a sort of "discursive machismo" (Gambetta, 1998).

Gutmann and Thompson (1996, p. 115) point out after Madison, was attributed to the fact that "members could speak candidly, change their positions, and accept compromises without constantly worrying about what the public and the press might say". This corresponds to Chambers' (2004) considerations on the impact of secrecy on the Socratic reason in deliberation. 
From this perspective, debates are always performed with audiences, since the reason why the debaters confront one another is to compete for the spectators' approval (sometimes expressed via voting). Thus, it takes a form of manipulation, pandering, or image-maintaining (Chambers, 2004, p. 393). Bargaining, on the other hand, should never occur in front of spectators, because participants would have difficulty in compromising with their integrity or honesty being judged from the outside. Deliberation as consultation can be said to be in a rather awkward position. It should have an audience (especially the decision-makers), who should be influenced by its process and conclusions. At the same time, however, it should be performed as if there was no audience (in the eyes of deliberators), so that the participants do not compete for any spectators' approval.

\subsection{Summary: Deliberation in Democratic Societies}

All these phenomena correspond to Alexis de Tocqueville's reflections on the persistence of views in a democracy. Contrary to the traditional criticism stating that it is based on the whim of masses (Gundersen, 2000, pp. 3-4), this political system provokes a petrification of preferences. A kind of relativism discovered in a free public sphere, paradoxically, makes the citizens stick to their convictions more fiercely. As the author says:

Since all social theories, one by one, have been contested and fought, those who are attached to one of them keep it, not so much because they are sure that it is good, as because they are not sure that there is a better one. (Tocqueville, 2010, p. 229)

Then he concludes, stating that:

[...] when [reasonable] opinions are doubted, men end up being attached solely to instincts and to material interests, which are much more visible, more tangible and more permanent by their nature than opinions are. [...] That is a self-evident truth; there is no need to discuss it; you are rich and I am poor. (Tocqueville, 2010, p. 230).

This remark presents the issue in a wider, systemic perspective. The decisional atrophy of deliberative stance is an overall petrification of opinions and results from a complex phenomenon that is typical of modern democracies; one that occurs when a given controversial issue (either ideologically or by virtue of being relevant to particular interests) is to be decided. In such case, a specific rhetoric is invoked, most commonly in the form of the discourse of 'crisis' and of the 'war of the worlds' (Tannen, 1999). With strong polarization, preferences become 'entrenched', which makes expectations with regard to a change of opinion among the participants of deliberation futile (Druckman et al., 2013). There is also a real risk that stakeholders will try to influence the course of deliberation itself by interfering with its objectivity and impartiality. Bearing this in mind, it is even recommended to use deliberative methods rapidly before the stakeholders manage to understand the situation and take an action, such as a media campaign (Abelson et al., 2003). Unfortunately, this recommendation cannot be implemented in the case of the institutionalization of deliberative procedures. Giving these methods decisional competences and a permanent place in 
the system also exposes them to constant pressures from various stakeholders; these pressures are aimed at the destruction of deliberative virtues among participants.

Ceding decision-making powers to deliberative bodies results in the gradual replacement of the educational aspect of discussion with antagonism. In such circumstances, the typical solution is to abandon the role of deliberative bodies as a place for free discussion and, simply, to turn them into a forum for voting and bargaining. This might have been the historical fate of the institutions of parliament all over Europe (Leydet, 2014). Originally, any given parliament was more of an advisory body to the monarch and a part of a more complex system of power that required the consent of various elements (de Jouvenel, 1957). In some cases, e.g. in $17^{\text {th }}$-century England, candidates for the Parliament abstained from declaring their opinions on a given issue in advance even though it was of great political significance (e.g. the religious and dynastic policies of James II right before the Glorious Revolution of 1688). Maurice Ashley (1966, p. 245) speculates that they were not willing to commit to any line of policy "until they had gathered together and thrashed things out". It is safe to say that in a contemporary parliamentary system such a deliberative attitude would be mercilessly punished by the media and/or the electorate. In the $17^{\text {th }}$ century, however, parliaments might have been the embodiment of the deliberative approach. With time, and with the expansion of parliamentary powers and the subsequent rise of organized political parties, they turned into the arena of ideological clashes and political bargains (Zabdyr-Jamróz, 2009; Leydet, 2014). In the end, the fact remains that modern democratic representative arrangements do not go well with the deliberative stance. ${ }^{6}$ Such are the consequences of representation; it tends to spoil the idea of free, authentic, and reasonable discussion in favor of a partisan eristic and an uncompromising mindset.

\section{Discussion: 'How to Deal with the Atrophy of Deliberative Stance?'}

Before I go further into the consequences of these considerations, I should emphasize that my intent was not to negate Cohen's (2007, p. 219) decision-oriented definition of deliberation, nor to ruthlessly shatter Arnstein's (1969) 'ladder of participation'. These concepts apply to other theoretical and practical purposes. The same is true for the notion of 'deliberative negotiation' (Warren \& Mansbridge, 2013). For the purposes of this paper, I merely wanted to try another theoretical approach and explore a different path in order to see whether this would lead me to a relevant conclusion. By so doing, I build upon the systemic approach to deliberative democracy, but also expand and develop several important details.

\footnotetext{
${ }^{6}$ Noble though it might have been, the eloquent Speech to the Electors of Bristol did not convince the electors; Edmund Burke had to abandon hopes for re-election from Bristol (Heffer, 2011, p. 30).
} 


\subsection{Developing the Deliberative Systems Approach}

The distinction between consultation and co-decision seems to resemble James Bohman's distinction between minipublics and minidemoi, but, in fact, it explores the issue in a different dimension. The latter typology clearly follows the "amount of power" approach that is represented by Arnstein's ladder of participation. Minipublic is the citizens' deliberative body that lacks decisional authority (e.g. a deliberative poll, citizen's jury, etc.), merely supplementing other democratic institutions. Minidemos, on the other hand, is a body that shares the minipublic's communicative status, but is also equipped with decisional powers (Bohman, 2012, pp. 72-93, 84-89). Therefore, minidemoi exist alongside other decisionmaking institutions, such as referendums or elected assemblies. On the ladder of participation, minidemos would be classified in terms of co-decision, whereas minipublic merely as consultation or tokenism.

My intent is to point out that, while being very appealing from the democratic point of view, minidemos is, in fact, a particularly fragile and unstable discursive arrangement; it is subject to the decisional atrophy of deliberative stance. Over time it will lean towards other forms of communication (debating and bargaining), hence losing its deliberative stance. In other words, I argue (or, rather, I fear) that in the longer systemic perspective, minidemos functioning in a more impactful political capacity (as a deliberative political decision-making body) might be an evolutionarily unstable institution.

Here, I also find John Parkinson's (2012, p. 169) appreciation of certain forms of representation and accountability (especially those based on election and self-appointment) as problematic. I do not reject them as illegitimate even for the process of deliberation (in fact, in my further research I intend to systematically reconcile deliberation with representation within deliberative governance approach). Rather, I point out that they do not go well with the deliberative stance. In fact they seem to be the main reason for the atrophy of deliberative stance even if representation is "based on flexible constituencies rather than a fixed, positional relationship between principals and agents" (Parkinson, 2012, p. 169). Also, I am not claiming that it is impossible for a representative to change her or his mind; I merely point out that it is much harder and often requires non-deliberative means. This is why (within the traditional co-decision-deliberative consultation dichotomy), I introduce the distinction between representation and presentation (representativeness through random selection), where citizens do not represent but, instead, "present themselves" (Badiou, 1988, pp. 95-115).

\subsection{Stepping Down Arnstein's Ladder?}

The conclusion of this theoretical proposal is somewhat unorthodox from the perspective of civic engagement movements. In order to promote the paradigm of social learning (concerted action through deliberation), instead of "jumping off the ladder of participation"as Collins and Ison (2006) metaphorically propose - perhaps it would prove more effective to step down onto some of the lower rungs. This notion might be hard to accept, especially 
in a world where citizens' empowerment is still glaringly inadequate. However, it should be noted that perhaps in order to facilitate social learning and improve the quality of our democracies, one should not always aim at the highest rungs of the ladder of participation, which is not to say that one should never aim for maximum empowerment.

One key point of the systemic approach is vital here. Namely, a given deliberative event does not have to be decisional in order to be more than just "idle talk", i.e. to have impact within the whole of deliberative system (Chambers, 2012). There are other actors (decision-makers), who listen and can be persuaded. If they are not subject to the partisan rhetoric and are not engaged in such a competition (being an attentive audience instead), they might be willing to shift their opinion over time (Mackie, 2006). More than this, over time such a preference change can lead to a substantial policy modification. This phenomenon is described by the concept of 'decision by accretion', which is an essential component within the systemic approach by Jane Mansbridge and others (2012, p. 8). It refers to a situation in which some decisions "have no clear-cut point at which an observer can say that a decision has been taken" and "can be seen as collective decisions". Being "based on widespread collective discussion and interaction", they are "emergent rather than definite". In this vein, the distinction between traditional co-decision and deliberative consultation is merely a logical conclusion of the systemic turn. It affirms and embraces the idea that deliberation does not have to (and even should not) be decisional ${ }^{7}$ in order to have a significant policy impact.

However, this is just one of the conclusions of this proposal. Now that it is clear what hinders deliberation when it is made decisional, perhaps it is possible to examine some of these factors more closely by isolating them and negating their impact. By doing so, one might just be able to combine a sufficient "amount" of power with a sufficient dose of deliberative social learning.

\subsection{Rhetorics}

What differentiates deliberative approaches is, in fact, the evaluation of rhetorics. More traditional deliberative democrats consider it a threat to the democratic process. As representatives of the "traditional political theory from Plato to Habermas", these thinkers equate rhetorics with emotive manipulation, propaganda, and demagoguery. Hence, what they want is to purge rhetorics from deliberation (Dryzek, 2002). Other theoreticians, however, point out that rhetorics should not be expelled from the debate due to freedom of expression, and that manipulation is very close to persuasion. Forms of communication that are similar

\footnotetext{
${ }^{7}$ That being said, there is an inherent problem with following this diagnosis. I would call it a 'decisional paradox of deliberation'. On the one hand, in order to perform its role, i.e. induce social learning, it might be preferable for deliberation not to be decisional. On the other hand, the emphasis on the non-decisional character is a serious threat to the representativeness of such deliberation. Research has shown that citizens' will to participate in timeconsuming and costly deliberation weakens significantly when they do not feel that their involvement will be of significance to the final decision (Abelson et al., 2003).
} 
to rhetorics, such as 'greeting' or 'storytelling', can make others feel welcome with their input in conversation, or draw attention to certain issues, making others aware of its importance and thus empowering previously marginalized categories of people (Young, 1996, pp. 130-131; 2000, pp. 23-27). Most notably, some forms of rhetorics - especially “bridging” gestures, but even irony (Basu, 1999; Lombardini, 2013), invective (Shiffman, 2002) or shaming (Tarnopolsky, 2007) - often serve an important deliberative goal of inducing a preference change (Dryzek, 2010b). Simone Chambers (2009) even goes as far as to distinguish "good", deliberative rhetorics from the "bad", plebiscitary kind. All this supports the rehabilitation of the persuasive aspect of rhetorics.

However, the problem of the detrimental systemic consequences of (plebiscitary) rhetorics for modern democracies remains. As James Fishkin (2011, p. 6) points out, “As our political process is colonized by the persuasion industry, as our public dialogue is voiced increasingly in advertising, our system has undertaken a long journey from Madison to Madison Avenue". As Chambers (2009, p. 33) puts it, "Plebiscitary rhetoric deploys speech strategically for the purposes of winning". It turns debate into arguing, i.e. an ordeal of words in an environment of the audience democracy and positional politics, with a minimal chance of preference change. Such rhetorics is a tool used most efficiently by the powerful in order to manipulate people and effectively disenfranchise them. This, as John Bohman (2012) points out, is one of the main challenges for the deliberative systems approach.

The classical deliberative democracy is generally sceptical towards rhetorics. While granting it raison d'être within the wider public and political sphere (Dryzek, 2002, pp. 165167), the deliberative theory generated a kind of 'defensive' or 'entrenching' (as opposed to expansive/systemic) approach that focuses on micro-deliberation. The intent is to create a sort of 'deliberative adytum' with the purpose of finding a preservation area for learned discussion within the public discourse. Such a discussion would be insulated "from certain negative or distorting effects of the broader public sphere" (Chambers, 2004, p. 400) shielded from detrimental "public pressures" (Pettit, 2013, p. 232), not contaminated by the fallout of rhetorics; the strategy of "mutually assured distraction" ("MAD") ${ }^{8}$ (Fishkin, 2011, pp. 4-5), an ideological "war of the worlds" (Tannen, 1999), and, eventually, deep ideological polarization (Klein, 2014).

This approach is not caused by some special disgust towards rhetorics in itself. In fact, persuasion has an important place in deliberation as a trigger for opinion change and reciprocity. However, one should also be aware of the fact that the hypertrophy of rhetorics (even of 'storytelling' when it is treated dishonestly) eventually leads to affective polarization (Webster \& Abramowitz, 2017), petrification of opinions, and - by definitionnegates deliberation, taking away its place in the public sphere. Therefore, the goal here is to protect this particularly fragile mode of communication (Owen \& Smith, 2013).

\footnotetext{
8 'Distraction' is replacing 'destruction' from the original MAD doctrine of the Cold War.
} 
All this leads to the micro-deliberative strategy, namely proposing the minipublic as such a deliberative adytum. Here, the deliberation can be shielded from the external distortions. In its most assertive form, the micro-deliberative strategy proposes that the minipublics should be made decisional, i.e. turned into minidemoi, in order to improve the entirety of the deliberative system. However, Cristina Lafont criticizes this stance by pointing to its strong elitist vibe: lay-citizens via deliberative process become experts of all sorts ${ }^{9}$. In her view, such a strategy "suggests that the only choices we have are between non-participatory deliberation and non-deliberative participation" (Lafont, 2015, p. 48). Thus, it "foreclose[s] large-scale quality deliberation" by presenting a de facto elite deliberation model, i.e. the deliberation of a selected minority of citizens, as the most viable option.

\subsection{The Open Siege of Alesia}

For the purposes of this paper I am suggesting that there is a systemic problem with a power-oriented micro-deliberative strategy. When a deliberative minipublic becomes decisional, it also becomes a target for pressures from stakeholders. Hence, as John Dryzek (2005) notes, deliberation should be kept at a certain distance from political power. Following Jürgen Habermas' stance (1996, pp. 486-487) that communicative power is exercised in the manner of a "self-limiting siege" of the state, I would like to further elaborate on this metaphor. Keeping deliberation in the public sphere, i.e. besieging the center of political decision-making, should not only hold back its pressure on the state (in order not to deplete the civil society, as Dryzek would put it), but also fortify itself from pressures from the outside (stakeholders, the for-profit sector, organized ideology proponents, etc.) Deliberation should be protected not only from the state, but also from other actors/spheres of civil society and public debate, mainly interest groups and the sectarian discourse. From the systemic perspective, what is important here is to preserve deliberative fora in order to allow vital exchange of information to occur at least in one part of the system so that it can influence its other, decisional elements.

Habermas' "siege" metaphor suggests a strategy known from the Gallic Wars of Julius Caesar as the Siege of Alesia. Caesar's tactics in this battle was to besiege the Gallic stronghold of Alesia. Not having enough soldiers, he could not just assault the city, so he fortified his positions against any attempts at breaking the blockade from the inside (cf. Habermas" "self-limiting siege"). Soon, however, a new threat became apparent; Gallic reinforcements were coming (stakeholders interference). At that point Caesar decided to fortify his positions also on the outside in order to defend the siege from an external attack. The very same tactics could be considered a guide for ensuring the proper place of deliberation in any democratic polity. It should exert pressure on (and fortify against) a center of power, while at the same time fortifying one's position against any external influences that would threaten the integrity of deliberation. The very same recommendations are

\footnotetext{
${ }^{9}$ I should note that, in my view, the validity of this interpretation is questionable.
} 
long-standing principles that guide e.g. the proceedings of trial juries in common law systems. This metaphor should not go so far as to suggest that deliberation should be completely insulated from the outside inputs, i.e. from arguments and reason (as information on relevant self-interests, emotions, and expertise). Rather, the idea is to protect it form factors that lead to the atrophy of the deliberative stance.

This, of course, is still a micro-deliberative strategy, but one that does not strive after direct power. It is defensive for the small-scale quality deliberations. However, while micro-deliberation should have its secured post in the siege of the state, it cannot monopolize access to it the way that the Siege of Alesia metaphor suggests. By blocking access of other inputs (most notably public debate and stakeholders' bargaining), deliberation would effectively expose itself to the decisional atrophy of deliberation. Hence, the deliberative siege should be open, allowing other discourses to besiege the state as well. In this proposition the final decision should be the interplay of those discourse types, competing against each other and complementing one another in the course of policy-making processes.

The Open Siege of Alesia Model of positioning deliberation fulfils both the defensive and the expansive roles for deliberative ideals, promoting a large-scale deliberative participation. If it is true that discourse types can spread also by means of popularity, then deliberation should have a bastion, i.e. a foothold in the discursive system that would provide an example of the deliberative stance, showing the way to inspire and spread just as much in everyday life as in key formal institutions. In other words, the Open Alesia Model uses the micro-deliberative strategy as a means to improve the quality of large-scale deliberation. It is consistent with the remarks by Michael MacKenzie and Mark Warren (2012), who stated that deliberative bodies could show "the right way" to the rest of the system, creating good habits and spreading good will and trust among citizens. However, having in mind Parkinson's (2012, p. 168) remark that "trust in institutions generally is in marked decline", one has to admit that the above-mentioned model relies on "blind faith" towards elitist deliberative bodies as decision-makers. The point here is for micro-deliberation to have a formal - not material-impact on the public sphere. It is not supposed to deliver decisions by dictating the supposed contents of learned public opinion, thus replacing public debate. Micro-deliberation should, however, inspire public debate by changing the way it is conducted, i.e. by raising public expectations, informing the public, promoting public learning, and proliferating quality deliberation in the public sphere. In other words, as Lafont (2015, p. 60) puts it, "Deliberative democrats should endorse the use of minipublics for shaping public opinion, not public policies".

In this instance, the Open Alesia Model does not rely on the micro-deliberative strategy exclusively, but it also calls for support at the macro level. It demands - again following Lafont (2015, p. 59) - the actual improvement of "the deliberative quality of the political discourse in the broad public sphere", a support that "may require structural changes such as improving the diversity of mass media and their independence from market pressures, strengthening the independence of political parties from concentrated wealth, political campaign reform, and so on". This will be the way to enhance citizens to a better-quality discourse. 
Here I can only outline the Open Siege of Alesia Model as a metaphor of positioning microdeliberation in the deliberative system. This notion will require further elaboration and tackling its various inherent challenges. One of the most apparent would be the aforementioned impact of publicity on the discourse quality. In order for the Open Alesia Model to workfor the quality deliberation to spread across the system - the deliberative mini-publics require an attentive audience that actually seeks political freedom in a profound way. However, the very same attention that allows people to learn from a good discursive example might, in the end, provoke the participants of deliberation to compete for attention and approval.

\section{Conclusions}

Donald Bello Hutt has associated deliberative democratic theory with political freedom via republican theory. His considerations led him to the principle of Equality of Access and Deliberation, i.e.

$[\ldots]$ the endorsement of $[\ldots]$ an egalitarian principle including all those potentially affected by collective decisions, securing the capacity of those individuals to form and transform their preferences in an autonomous fashion, and providing them with the opportunity to participate in the deliberative process through which collective decisions shall be adopted. (Hutt, 2018, p. 104)

I argue that in order to secure this "capacity to form and transform preferences in an autonomous fashion", i.e. to exercise political freedom meaningfully in the light of Hannah Arendt's understanding of revolution, a formal access to power might not be required and, in fact, can be detrimental.

Participation in government cannot be a mere cooptation that often takes form of the technology of manufacturing legitimation (Harrison \& Mort, 1998; Wallington, Lawrence, \& Loechel, 2008). Political freedom requires an ability to exercise power meaningfully, i.e. to comprehend the complexity of the world and to see through the pre-established ideologies, the plebiscitary rhetorics of partisans, and the white noise of mediatized politics. It requires prerequisites to release itself form the Procrustes bed of status quo and see political alternatives beyond what is seemingly obvious, i.e. beyond entrenched political doctrines, immediate emotional impulses, and fixed self-interests. In other words, it requires an imaginative capacity for deliberative change, which will make it possible to see and to better understand policy determinants and truly available options.

The deliberative stance is a fragile attitude; there are various factors that cause its atrophy. By adopting the systemic approach, I pinpoint some institutional factors that generate this atrophy of deliberation. I find out that participants of discussion become more opinionated when they: are representatives; are in the presence of an audience; or have the prospect of a binding decision. The last one, i.e. the decisional atrophy of deliberative stance, correlates with the former two. The purpose of this paper was to show these structural hindrances to deliberation; that the actual roles performed in participation shape its character and outcomes. These circumstances, I argue, hinder not only the quality of public discussion, but also the real political freedom of citizens by limiting their scope of political and 
policy options. Therefore, I add more arguments to Lafont's (2015) critique of a microdeliberative strategy that promotes decisional minipublics or minidemoi, as Bohman (2012) would call them. I demonstrate how problematic deliberative decision-making can be, as the finest example of Dryzek's (2002, p. 111) paradox when a "more democratic state" results in a "less democratic polity" shows. All this leads me to the conclusionand a notion that should at least be entertained - that on some occasions it is better that, in order to preserve their deliberative character in the systemic context, deliberative minipublics do not have decision-making powers. To preserve the deliberative stance from its atrophy, I have also proposed the Open Siege of Alesia Model for positioning deliberation in a wider deliberative system.

\section{References}

Abelson, J., Forest, P.-G., Eyles, J., Smith, P., Martin, E., \& Gauvin, F.-P. (2003). Deliberations about deliberative methods: Issues in the design and evaluation of public participation processes. Social Science \& Medicine, 57(2), 239-251.

Adams, J. (2011). Discourses on Davila: A Series of Papers, on Political History. Written in the Year 1790, and then Published in the Gazette of the United States (Vol. VI). Boston, MA: Nabu Press.

Arendt, H. (1990). On Revolution. London, UK: Penguin Books.

Arnstein, S. R. (1969). A Ladder of Citizen Participation. Journal of the American Institute of Planners, 35(4), 216-224.

Ashley, M. (1966). The Glorious Revolution of 1688. London, UK: Hodder \& Stoughton.

Bächtiger, A., Niemeyer, S., Neblo, M., Steenbergen, M. R., \& Steiner, J. (2010). Disentangling Diversity in Deliberative Democracy: Competing Theories, Their Blind Spots and Complementarities. Journal of Political Philosophy, 18(1), 32-63.

Badiou, A. (1988). L'Être et l'Événement. Paris, France: Seuil.

Basu, S. (1999). Dialogic Ethics and the Virtue of Humor. Journal of Political Philosophy, 7(4), 378-403.

Bohman, J. (2012). Representation in the Deliberative System. In J. Parkinson \& J. J. Mansbridge (Eds.), Deliberative Systems (pp. 72-94). New York, NY: Cambridge University Press.

Chambers, S. (2004). Behind Closed Doors: Publicity, Secrecy, and the Quality of Deliberation. Journal of Political Philosophy, 12(4), 389-410.

Chambers, S. (2009). Rhetoric and the Public Sphere Has Deliberative Democracy Abandoned Mass Democracy? Political Theory, 37(3), 323-350.

Chambers, S. (2012). Deliberation and Mass Democracy. In J. Parkinson \& J. J. Mansbridge (Eds.), Deliberative Systems (pp. 52-71). New York: Cambridge University Press. 
Cohen, J. (2007). Deliberative Democracy. In S. W. Rosenberg (Ed.), Deliberation, Participation, and Democracy: Can the People Govern? (pp. 219-236). New York: Palgrave Macmillan.

Collins, K., \& Ison, R. (2006). Dare we Jump off Arnstein's Ladder? Social Learning as a New Policy Paradigm. Presented at the Proceedings of PATH (Participatory Approaches in Science $\&$ Technology) Conference, Edinburgh.

Deveaux, M. (2003). A Deliberative Approach to Conflicts of Culture. Political Theory, 31(6), $780-807$.

Dobson, A. (2014). Listening for Democracy: Recognition, Representation, Reconciliation. Oxford, UK: Oxford University Press.

Druckman, J. N., Peterson, E., \& Slothuus, R. (2013). How Elite Partisan Polarization Affects Public Opinion Formation. American Political Science Review, 107(1), 57-79. https://doi.org/10.1017/S0003055412000500

Dryzek, J. S. (2002). Deliberative Democracy and Beyond: Liberals, Critics, Contestations. New York, NY: Oxford University Press.

Dryzek, J. S. (2005). Deliberative Democracy in Divided Societies Alternatives to Agonism and Analgesia. Political Theory, 33(2), 218-242.

Dryzek, J. S. (2010a). Foundations and Frontiers of Deliberative Governance. New York, NY: Oxford University Press.

Dryzek, J. S. (2010b). Rhetoric in democracy: A systemic appreciation. Political Theory, 38(3), 319-339.

Elster, J. (1983). Sour Grapes: Studies in the Subversion of Rationality. Cambridge, UK: Cambridge University Press.

Elstub, S., \& McLaverty, P. (2013). Ten Issues for a Deliberative System (APSA 2013 Annual Meeting No. ID 2303026). Rochester, NY: American Political Science Association.

Fishkin, J. S. (1991). Democracy and Deliberation: New Directions for Democratic Reform. New Heven, CT: Yale University Press.

Fishkin, J. S. (2011). When the People Speak: Deliberative Democracy and Public Consultation. New York, NY: Oxford University Press.

Fishkin, J. S., Luskin, R. C., \& Jowell, R. (2000). Deliberative Polling and Public Consultation. Parliamentary Affairs, 53(4), 657-666.

Fuerstein, M. (2014). Democratic Consensus as an Essential Byproduct. Journal of Political Philosophy, 22(3), 282-301.

Fung, A. (2003). Recipes for Public Spheres. Journal of Political Philosophy, 11(3), 338-367.

Gambetta, D. (1998). Claro! An Essay on Discursive Machismo. In J. Elster (Ed.), Deliberative Democracy (pp. 19-43). Cambridge, UK: Cambridge University Press.

Goodin, R. E. (2000). Democratic Deliberation Within. Philosophy \& Public Affairs, 29(1), 81-109.

Goodin, R. E. (2008). Innovating Democracy. New York, NY: Oxford University Press. 
Gundersen, A. G. (2000). The Socratic Citizen: A Theory of Deliberative Democracy. New York, NY: Lexington Books.

Gutmann, A., \& Thompson, D. F. (2012). The Spirit of Compromise: Why Governing Demands It and Campaigning Undermines It. Princeton, NJ: Princeton University Press.

Habermas, J. (1996). Between Facts and Norms: Contributions to a Discourse Theory of Law and Democracy. Cambridge, MA: MIT Press.

Habermas, J. (2002). The Inclusion of the Other: Studies in Political Theory. Cambridge, MA: MIT Press.

Hajer, M. A. (Ed.). (2009). Authoritative Governance: Policy Making in the Age of Mediatization. Oxford, UK: Oxford University Press.

Harrison, S., \& Mort, M. (1998). Which Champions, Which People? Public and User Involvement in Health Care as a Technology of Legitimation. Social Policy \& Administration, 32(1), 60 70. https://doi.org/10.1111/1467-9515.00086

Heffer, S. (2011). Editor's Commentary to: 'Edmund Burke on the Responsibilities of a Member of Parliament'. In Great British Speeches (pp. 29-30). London, UK: Quercus.

Held, D. (2006). Models of Democracy. Cambridge, UK: Polity Press.

Hendriks, C. M. (2006). Integrated Deliberation: Reconciling Civil Society's Dual Role in Deliberative Democracy. Political Studies, 54(3), 486-508.

Hutt, D. B. (2018). Republicanism, Deliberative Democracy, and Equality of Access and Deliberation. Theoria, 84(1), 83-111.

Jouvenel, B. de. (1957). On the Developement of the Sovereign Will. In J. F. Huntington (Trans.), Sovereignty: An Inquiry into Political Good (pp. 169-186). Chicago, IL: University of Chicago Press.

Kahan, D. M., Peters, E., Dawson, E. C., \& Slovic, P. (2013). Motivated Numeracy and Enlightened Self-Government. Yale Law School, The Cultural Cognition Project, Working Paper, 1(307), $54-86$.

Kahane, D., Loptson, K., Herriman, J., \& Hardy, M. (2013). Stakeholder and Citizen Roles in Public Deliberation. Journal of Public Deliberation, 9(2), 1-35.

Keyes, R. (2004). The Post-Truth Era: Dishonesty and Deception in Contemporary Life. London, UK: Macmillan.

Klein, E. (2014, July 29). The Single Most Important Fact About American Politics. Retrieved from http://www.vox.com/2014/6/13/5803768/pew-most-important-fact-american-politics

Kosnoski, J. (2005). Artful Discussion John Dewey's Classroom as a Model of Deliberative Association. Political Theory, 33(5), 654-677.

Lafont, C. (2015). Deliberation, Participation, and Democratic Legitimacy: Should Deliberative Mini-publics Shape Public Policy? Journal of Political Philosophy, 23(1), 40-63.

Landwehr, C. (2010). Discourse and Coordination: Modes of Interaction and their Roles in Political Decision-Making. Journal of Political Philosophy, 18(1), 101-122. 
Landwehr, C., \& Holzinger, K. (2010). Institutional Determinants of Deliberative Interaction. European Political Science Review, 2(03), 373-400.

Leydet, D. (2014). Partisan Legislatures and Democratic Deliberation. Journal of Political Philosophy, 23(3), 235-260.

Lombardini, J. (2013). Civic Laughter Aristotle and the Political Virtue of Humor. Political Theory, 41(2), 203-230.

MacKenzie, J., \& Warren, M. E. (2012). On the Embeddedness of Deliberative Systems: Why Elitist Innovations Matter More. In J. Parkinson \& J. J. Mansbridge (Eds.), Deliberative Systems (pp. 125-150). New York, NY: Cambridge University Press.

Mackie, G. (2006). Does democratic deliberation change minds? Politics, Philosophy \& Economics, 5(3), 279-303.

Mansbridge, J. J. (2015). A Minimalist Definition of Deliberation. In P. Heller \& V. Rao (Eds.), Deliberation and Development (pp. 27-49). Washington, DC: World Bank.

Mansbridge, J. J., Bohman, J., Chambers, S., Christiano, T., Fung, A., Parkinson, J., ... Warren, M. E. (2012). A Systemic Approach to Deliberative Democracy. In J. Parkinson \& J. Mansbridge (Eds.), Deliberative Systems (pp. 1-26). New York: Cambridge University Press.

Mariotti, S. L. (2014). Adorno on the Radio: Democratic Leadership as Democratic Pedagogy. Political Theory, 42(4), 415-442.

Owen, D., \& Smith, G. (2013). Two Types of Deliberative System. Presented at the 2013 Annual Meeting of the American Political Science Association, Chicago, IL: American Political Science Association.

Owen, D., \& Smith, G. (2015). Survey Article: Deliberation, Democracy, and the Systemic Turn. Journal of Political Philosophy, 23(2), 213-234.

Parkinson, J. (2012). Democratizing Deliberative Systems. In J. Parkinson \& J. J. Mansbridge (Eds.), Deliberative Systems (pp. 151-172). New York: Cambridge University Press.

Pettit, P. (2013). On the People's Terms: A Republican Theory and Model of Democracy. Cambridge, UK: Cambridge University Press.

Schmitt, C. (1988). The Crisis of Parliamentary Democracy. Cambridge, MA: MIT Press.

Schopenhauer, A. (2005). The Art of Always Being Right. London, UK: Gibson Square.

Shapiro, I. (1999). Enough of Deliberation. Politics is about Interests and Power. In S. Macedo (Ed.), Deliberative Politics: Essays on Democracy and Disagreement (pp. 28-38). Oxford, UK: Oxford University Press.

Shapiro, I. (2003). The State of Democratic Theory. Princeton, NJ: Princeton University Press.

Shiffman, G. (2002). Construing Disagreement Consensus and Invective in "Constitutional" Debate. Political Theory, 30(2), 175-203.

Skultety, S. C. (2009). Competition in the Best of Cities Agonism and Aristotle's Politics. Political Theory, 37(1), 44-68. 
Smith, G. (2013). Two Ideals of Deliberation? (SSRN Scholarly Paper No. ID 2301672). Rochester, NY: Social Science Research Network.

Steenbergen, M. R., Bächtiger, A., Spörndli, M., \& Steiner, J. (2003). Measuring Political Deliberation: a Discourse Quality Index. Comparative European Politics, 1(1), 21-48.

Suiter, J., Farrell, D. M., \& O’Malley, E. (2014). When do Deliberative Citizens Change their Opinions? Evidence from the Irish Citizens' Assembly. International Political Science Review.

Tannen, D. (1999). The Argument Culture: Stopping America's War of Words. New York, NY: Ballantine Books.

Tarnopolsky, C. (2007). Platonic Reflections on the Aesthetic Dimensions of Deliberative Democracy. Political Theory, 35(3), 288-312.

Tetlock, P. (2005). Expert Political Judgment: How Good is it? How Can We Know? Princeton, NJ: Princeton University Press.

Thompson, D. F. (2008). Deliberative Democratic Theory and Empirical Political Science. Annual Review of Political Science, 11(1), 497-520.

Tocqueville, A. de. (2010). Democracy in America: Historical-Critical Edition. (J. T. Schleifer, Trans.). Indianapolis, IN: Liberty Fund, Incorporated.

Tritter, J. Q., \& McCallum, A. (2005). The Snakes and Ladders of User Involvement: Moving Beyond Arnstein. Health Policy (76), 156-168.

von Rautenfeld, H. (2004). Charitable Interpretations Emerson, Rawls, and Cavell on the Use of Public Reason. Political Theory, 32(1), 61-84.

Wagner, A. (2014). Shale gas: Energy Innovation in a (Non-)Knowledge Society: A Press Discourse Analysis. Science and Public Policy, 42(5), 1-14.

Wallington, T., Lawrence, G., \& Loechel, B. (2008). Reflections on the Legitimacy of Regional Environmental Governance: Lessons from Australia's Experiment in Natural Resource Management. Journal of Environmental Policy \& Planning, 10(1), 1-30. https://doi.org/10.1080/15239080701652763

Warren, M. E., \& Mansbridge, J. J. (2013). Deliberative Negotiation. In J. Mansbridge \& C. J. Martin (Eds.), Negotiating Agreement in Politics (pp. 86-120). Washington, DC: American Political Science Association.

Webster, S. W., \& Abramowitz, A. I. (2017). The Ideological Foundations of Affective Polarization in the U.S. Electorate. American Politics Research, 45(4), 621-647. https://doi.org/10.1177/1532673X17703132

Young, I. M. (1996). Communication and the Other: Beyond Deliberative Democracy. In S. Benhabib (Ed.), Democracy and Difference: Contesting the Boundaries of the Political (pp. 120 135). Princeton, NJ: Princeton University Press.

Young, I. M. (2000). Inclusive Political Communication: Greeting, Rhetoric and Storytelling in the Context of Political Argument. In Inclusion and Democracy. (pp. 52-83). Oxford, UK: Oxford University Press. 
Zabdyr-Jamróz, M. (2009). Gdzie jest Sklep z Gadaniną? Czyli Kilka Uwag o Suwerenności na Podstawie Ujęcia Parlamentaryzmu przez Carla Schmitta. In Politikon. Publikacja Pokonferencyjna (pp. 51-62). Kraków: KNP UJ.

Zabdyr-Jamróz, M. (2011). Perspektywy Sondażu Deliberatywnego jako Innowacji w Polityce Zdrowotnej. Zeszyty Naukowe Ochrony Zdrowia Zdrowie Publiczne i Zarzadzanie, 7(2), 30-46. 